\title{
Pembelajaran Berbasis Teknologi Untuk Generasi Z
}

\author{
Yusuf, E. \\ Program Studi Teknik Sipil \\ Universitas Pembangunan Jaya \\ eddy.yusuf@upj.ac.id
}

\begin{abstract}
This paper discusses an innovative technology-based teaching strategy to maximize the engagement of generation $Z$ in classrooms. An android-based tablet with Speedy Spectrum Analyzer application is used to discuss the standing wave topic in grade XII Physics. The rationale for the choice of the technology used in this paper is twofold: 1) the simplicity and availability and 2) the accuracy of the measured quantities by the equipment and application. We discuss how using this cheap and readily available piece of technology allows students to get a better understanding on difficult concepts, thus minimize misconceptions commonly found in this topic.
\end{abstract}

Keywords : generation Z, standing wave, physics, technology, tablet, android

\begin{abstract}
Abstrak : Makalah ini membahas sebuah strategi pembelajaran berbasis teknologi yang diperlukan untuk menghadapi generasi Z. Tablet berbasis android dengan perangkat lunak Speedy Spectrum Analyzer digunakan untuk menjelaskan materi gelombang stasioner pada mata pelajaran Fisika kelas XII. Titik berat dari penerapan teknologi ini dalam pembelajaran adalah 1) kemudahan untuk mendapatkan perangkat yang digunakan dan 2) keakuratan hasil yang diperoleh dari perangkat ini. Penggunaan teknologi ini diharapkan mempertajam konsep dan sekaligus mengikis miskonsepsi siswa dalam materi gelombang stasioner.
\end{abstract}

Kata Kunci : generasi Z, gelombang stasioner, fisika, teknologi, tablet, android

\section{PENDAHULUAN}

Perkembangan teknologi dan aliran informasi terjadi sangat pesat dalam kurun waktu 10 tahun terakhir. Pesatnya laju perkembangan teknologi ini berdampak pada perubahan gaya hidup, pola pikir, cara belajar, dan aspek-aspek kehidupan lainnya. Dampak terbesar dirasakan oleh generasi yang lahir dan/atau tumbuh pada masa terjadinya ledakan teknologi ini; generasi ini dikenal dengan sebutan "generasi Z". Generasi Z ini memiliki karakter yang unik dan sangat berbeda dengan karakter yang dimiliki oleh generasi-generasi sebelumnya. Pengaruh teknologi yang sangat kuat ini tercermin pada, misalnya, ketergantungan generasi $\mathrm{Z}$ dengan gadget dan durasi konsentrasi yang singkat (Ozkan \& Solmaz, 2015).
Saat ini populasi generasi $\mathrm{Z}$ yang berada pada usia aktif sekolah baik pada tingkat sekolah dasar maupun pada tingkat pendidikan tinggi sangat besar (Biro Pusat Statistik, 2015). Menghadapi generasi $\mathrm{Z}$ yang sangat dekat dengan teknologi, memiliki kecenderungan hiperaktif, penuh percaya diri, dan mudah bosan, inovasi dan terobosan dalam metode pengajaran sangat diperlukan, di mana guru berperan sebagai fasilitator (Kelly, 2008). Guru memerlukan strategi yang jitu yang memberikan kesempatan yang seluasluasnya untuk siswa untuk bereksperimen dan eksplorasi pada sebuah topik.

Makalah ini membahas sebuah strategi pengajaran dengan basis teknologi untuk mencapai penyerapan maksimum oleh siswa. Ada 2 kriteria yang perlu diperhatikan dalam penggunaan teknologi 
di kelas: 1) kemudahan untuk mendapatkan teknologi yang akan digunakan dan 2) keakuratan teknologi yang digunakan dalam memperoleh hasil yang diinginkan. Perangkat teknologi yang dipilih adalah sebuah tablet berbasis android, sebuah teknologi yang digunakan cukup meluas pada berbagai kalangan saat ini, yang digunakan untuk menjelaskan materi gelombang stasioner pada mata pelajaran Fisika kelas XII. Speedy Spectrum Analyer, sebuah software pendukung yang diunduh dari Google Play Store (Google Play Store, 2016), memperlengkapi tablet android ini dalam analisis frekwensi gelombang stasioner.

Sistematika makalah ini adalah sebagai berikut: paparan teori gelombang stasioner akan ditampilkan pada Bab 2 . Pada Bab 3, penulis akan membahas metodologi yang digunakan dalam penelitian ini, mulai dari pembahasan alat yang digunakan, pengambilan data, dan analisis. Bab ini juga akan membahas peluang penerapan metodologi ini di kelas dan aspek-aspek pengembangan yang dapat dilakukan untuk memperkaya metodologi yang dibahas pada makalah ini. Makalah ini ditutup dengan kesimpulan yang disajikan pada Bab 4.

\section{GELOMBANG STASIONER}

Suara yang kita dengar, dari suara dentuman meriam sampai suara yang melodi musik yang merdu, dihasilkan oleh objek yang bergetar. Alat musik menghasilkan suara dari getaran yang disebabkan oleh berbagai sumber. Sebagai contoh suara yang dihasilkan oleh klarinet berasal dari sebuah material tipis yang bergetar ketika udara lewat, suara piano dihasilkan oleh getaran senar piano, dan suara seorang penyanyi berasal dari getaran pita suara sang penyanyi. Getaran yang merambat sebagai fungsi ruang dan waktu dikenal sebagai gelombang. Gelombang stasioner adalah sebuah pola yang terbentuk ketika dua buah gelombang dengan cepat rambat, frekwensi dan amplitudo yang sama merambat dalam arah yang berlawanan dan berinteraksi satu sama lain (Serway, Faughn, Vuille, \& Bennett, 2010). Gelombang stasioner dapat diwujudkan dengan menggunakan tali yang teregang, dengan mengikat salah satu ujung tali ke penjepit dan ujung yang lain ke sumber getaran. Gelombang yang merambat dari sumber getaran akan berinterferensi dengan gelombang yang dipantulkan pada ujung yang terikat sehingga membentuk pola maksimum dan minimum. Secara matematis, kasus seperti ini disebut dengan gelombang stasioner dengan 2 ujung terikat. Rekaman sesaat pola maksimum dan minimum untuk gelombang stasioner dengan 2 ujung terikat ditampilkan pada Gambar 1. Pola maksimum dan minimum pada gelombang stasioner dapat dinyatakan oleh besaran frekwensi. Frekwensi suara pada gelombang stasioner dengan 2 ujung terikat bergantung pada cepat rambat suara di medium, $v$, di mana gelombang itu merambat dan panjang tali, $L$, yang berada pada 2 jepit dengan hubungan matematis berikut

$$
f_{n}=\frac{v}{2 L} n
$$

di mana $n=1,2,3 \ldots$ adalah orde frekwensi suara yang dihasilkan. Nilai $n=1$ adalah suara dengan frekwensi paling rendah, yang dikenal dengan sebutan frekwensi fundamental. Semakin besar nilai $n$ semakin tinggi frekwensi yang dihasilkan, yang umumnya disebut dengan frekwensi orde 2, 3, dan seterusnya. Kebanyakan siswa tidak mengalami kesulitan untuk melakukan perhitungan sederhana pada Persamaan 1, namun siswa umumnya sulit mencerna konsep orde frekwensi seperti ditampilkan pada Persamaan 1 ini dengan sempurna. Karena pemahaman yang dimiliki siswa adalah gelombang stasioner hanya memiliki satu frekwensi pada order tertentu.

Pada Gambar 1, panjang senar didefinisikan dengan $L$. Empat orde 
terendah ditampilkan pada ilustrasi ini. Orde terendah atau frekwensi fundamental diperoleh ketika panjang senar tepat sebesar $\lambda / 2$, di mana $\lambda$ adalah panjang gelombang. Orde-orde yang lebih tinggi terwujud ketika panjang senar melupakan kelipatan $\lambda / 2$, yaitu $\lambda, 3 \lambda / 2$, dan $2 \lambda$.

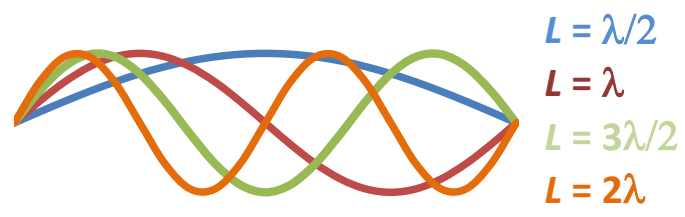

Gambar 1. Ilustrasi gelombang stasioner yang direkam pada saat tertentu.

\section{ANALISIS FREKWENSI GELOMBANG STASIONER}

Alat musik biola merupakan salah satu contoh sistem yang dapat digunakan untuk mensimulasikan prinsip gelombang stasioner dengan dua ujung terikat. Biola dimainkan pada nada $\mathrm{C}_{5} \#$ yang memiliki frekwensi $554 \mathrm{~Hz}$ (Frequencies for equaltempered scale, 2016). Untuk menghindari kontribusi suara dari latar belakang yang akan menambah kesulitan analisis, penulis memastikan suara dari ruangan pada kondisi yang cukup hening sebelum merekam suara dari gesekan biola. Rekaman suara gesekan biola dilakukan dengan menggunakan software Speedy Spectrum Analyzer di tablet berbasis android; hasil rekaman ditampilkan pada Gambar 1. Speedy Spectrum Analyzer menunjukkan adanya puncak-puncak spektrum suara dengan intensitas yang tinggi yang terwujud pada frekwensi tertentu.

Tabel 1 menampilkan nilai frekwensi di mana puncak-puncak ini teramati. Speedy Spectrum Analyzer mencatat jumlah puncak yang cukup banyak, namun dalam makalah ini hanya ditampilkan 20 puncak pertama karena penambahan tampilan puncak yang ke-21 dan seterusnya tidak mengubah konsep dasar yang akan disampaikan ke siswa. Frekwensi fundamental yang terbaca oleh Speedy Spectrum Analyszer adalah 559 $\mathrm{Hz}$; nilai ini berada pada rentang $1 \%$ ketidakpastian terhadap nilai literatur. Hal ini menunjukkan bahwa perangkat lunak Speedy Spectrum Analyzer dapat digunakan untuk memetakan frekwensi suara dengan keakuratan yang baik.

Aspek pembelajaran untuk siswa pada kasus ini dipusatkan pada terbentuknya resonansi gelombang stasioner. Pada umumnya pemahaman siswa untuk konsep gelombang stasioner terjadi pada level segmental; siswa cenderung memahami terbentuknya gelombang stasioner pada senar biola hanya terjadi untuk orde tertentu saja, misalnya orde 3. Alat bantu berbasis teknologi yang mengedepankan aspek visualisasi dapat membantu siswa mendalami konsep bahwa ketika senar biola digesek, suara yang dihasilkan merupakan gabungan dari semua frekwensi/orde yang mungkin sesuai dengan panjang senar dan material senar yang digunakan. Hal ini ditunjukkan dengan munculnya puncak-puncak resonansi dengan frekwensi yang berbeda dengan frekwensi fundamental seperti ditampilkan pada Gambar 1 dan Tabel 1.

Data Speedy Spectrum Analyzer juga dapat digunakan untuk menghitung perbandingan frekwensi antara orde yang berurutan. Secara teoritis, perbandingan antara frekwensi orde tertentu dengan 1 orde yang lebih tinggi dapat dihitung dari Persamaan 1

$$
\frac{f_{n+1}}{f_{n}}=\frac{n+1}{n}
$$

di mana $f_{n}\left(f_{n+1}\right)$ adalah frekwensi orde ke $n(n+1)$. Di sini dapat dilihat bahwa perbandingan frekwensi antara 2 orde yang berurutan tidak bergantung pada panjang senar dan jenis senar yang digunakan, namun hanya bergantung pada jenjang ordenya saja. Gambar 2 menampilkan perbandingan secara teoritis (kotak) dan eksperimen (biru). Hasil eksperimen 
diperoleh dengan menghitung perbandingan frekwensi antara, misalnya, orde ke 5 dan 4 yang nilai frekwensi tercantum pada Tabel 1. Di sini jelas terlihat bahwa hasil eksperimen memiliki kecocokan dengan nilai teoritis dengan keakuratan yang tinggi.

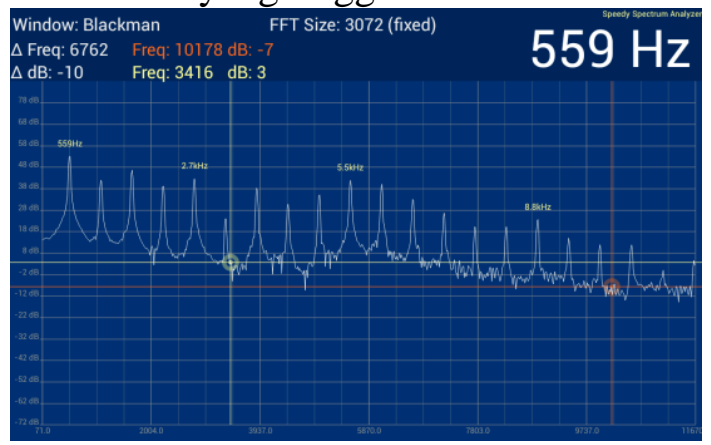

Gambar 2. Tampilan hasil rekaman perangkat lunak Speedy Spectrum Analyzer untuk nada $\mathrm{C}_{5} \#$.

Tabel 1. Frekwensi Gelombang Stasioner Yang Terekam Oleh Speedy Spectrum Analyzer

\begin{tabular}{|c|c|c|c|}
\hline Orde & $\begin{array}{c}\text { Frekwensi } \\
(\mathrm{Hz})\end{array}$ & Orde & $\begin{array}{c}\text { Frekwensi } \\
(\mathrm{Hz})\end{array}$ \\
\hline 1 & 559 & 11 & 6116 \\
\hline 2 & 1127 & 12 & 6664 \\
\hline 3 & 1675 & 13 & 7215 \\
\hline 4 & 2235 & 14 & 7769 \\
\hline 5 & 2781 & 15 & 8323 \\
\hline 6 & 3328 & 16 & 8883 \\
\hline 7 & 3892 & 17 & 9427 \\
\hline 8 & 4450 & 18 & 9991 \\
\hline 9 & 5005 & 19 & 10548 \\
\hline 10 & 5556 & 20 & 11108 \\
\hline
\end{tabular}

Orde 1 adalah frekwensi terendah yang disebut dengan frekwensi fundamental. Orde ke 2 dan seterusnya adalah orde resonansi yang muncul pada senar biola ketika digesek.

Gambar 3 memperlihatkan perbandingan frekwensi resonansi gelombang stasioner untuk orde $n+1$ dan $n$. Simbol kotak merah adalah perhitungan teoritis dan simbol biru adalah perhitungan yang diperoleh dari data eksperimen dari Speedy Spectrum Analyzer. Data teoritis dan eksperimen hampir berhimpit satu sama lain yang menunjukkan keakuratan metode yang digunakan.

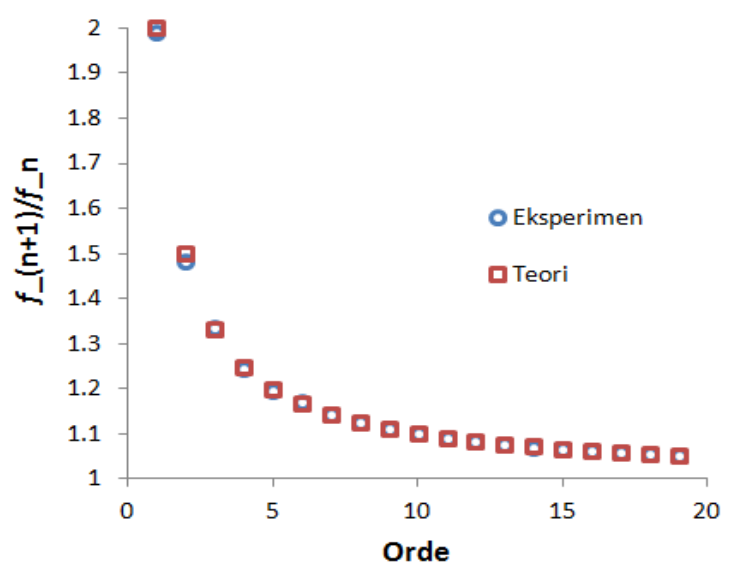

Gambar 3. Perbandingan frekwensi resonansi gelombang stasioner untuk orde $n+1$ dan $n$.

\section{KESIMPULAN}

Makalah ini membahas sebuah strategi inovasi pembelajaran yang bertumpu pada teknologi untuk memaksimalkan daya serap siswa yang masuk dalam kategori generasi Z. Fokus dari makalah ini adalah penggunaan perangkat lunak Speedy Spectrum Analyzer pada sebuah tablet android yang diterapkan pada materi gelombang stasioner untuk mata pelajaran Fisika kelas XII. Ada dua keunggulan dalam inovasi ini yaitu 1) perangkat lunak dan keras mudah didapat dan 2) analisis menunjukkan bahwa hasil pengukuran dengan alat ini akurat. Diharapkan dengan sebuah pendekatan yang baru, pemahaman konsep gelombang stasioner pada siswa dapat meningkat serta miskonsepsi dapat semakin dikikis.

\section{DAFTAR PUSTAKA}

1. Biro Pusat Statistik, 2015, Retrieved from Persentase Penduduk Usia 7-24 Tahun Menurut Jenis Kelamin, Kelompok Umur Sekolah, dan Partisipasi Sekolah 1, 20022014:

https://www.bps.go.id/linkTabelStatis/vie $\mathrm{w} / \mathrm{id} / 1533$ 
2. Frequencies for equal-tempered scale, 2016, Retrieved from Physics of MusicNotes:

http://www.phy.mtu.edu/ suits/notefreqs. $\underline{\mathrm{html}}$

3. Google Play Store, 2016, Retrieved from Speedy Spectrum Analyzer: https://play.google.com/store/apps/details ?id=com.electronchaos.SpeedySpectrum Analyzer

4. Kelly, C., 2008, Teacher as Facilitator of Learning. In P. Mårtensso, \& M. Bild,
Teaching and Learning at Business Schools: Transforming Business Education.

5. Ozkan, M., \& Solmaz, B., 2015, Mobile Addiction of Generation $Z$ and Its Effects. Procedia - Social and Behavioral Sciences , 205, 92-98.

6. Serway, R. A., Faughn, J. S., Vuille, C., \& Bennett, C. A., 2010, College Physics Thompson. 